\title{
Perbaikan Tata Letak Fasilitas Produksi Incoming Material Menggunakan Systematic Layout Planning di PT. Pan Brothers Tbk Boyolali
}

\author{
Fuji Tori Kebela1), Bambang Suhardi*2), Cucuk Nur Rosyidi ${ }^{3)}$, dan Iksan Adiasa ${ }^{4)}$ \\ ${ }^{1,2,3)}$ Teknik Industri, Fakultas Teknik, Universitas Sebelas Maret, \\ Jl. Ir. Sutami No.36 A, Surakarta, 57126, Indonesia \\ 4) Teknik Industri, Fakultas Teknik, Universitas Teknologi Sumbawa, \\ Jl Raya Olat Maras, Kabupaten Sumbawa, Nusa Tenggara Bar. 84371. Indonesia
}

DOI: 10.20961/performa.19.1.40093

\begin{abstract}
Abstrak
PT. Pan Brothers Tbk Boyolali merupakan perusahaan tekstil yang memproduksi berbagai macam pakaian olahraga. PT. Pan Brothers Tbk Boyolali memiliki beberapa permasalahan yang berkaitan dengan tata letak seperti ketiga jarak perpindahan terbesar yaitu perpindahan dari area warehouse table ke area before inspection sebesar 51,8 meter, perpindahan dari area rak roll kain ke area mesin c-tex sebesar 35 meter, dan perpindahan dari area before inspection ke area quality fabric table sebesar 34,8 meter. Semakin jauh jarak perpindahan barang semakin tinggi pula biaya material handling. Alasan lain perbaikan tata letak perlu dilakukan adalah seringnya dilakukan perubahan layout yang disebabkan oleh project dari atasan dan belumnya menggunakan metode apapun. Terjadinya penumpukan material roll kain yang disebabkan penempatan material ditaruh di gang yang membuat terhalangnya jalan perpindahan barang. Total waktu aktivitas produksi di incoming material melebihi waktu yang ditetapkan perusahaan yaitu 5 sampai 6 hari. Teknik pengumpulan data dalam penelitian ini yaitu dengan melakukan observasi secara langsung dan wawancara kepada pekerja. Dengan metode Systematic Layout Planning (SLP), dapat dihasilkan lebih dari satu alternatif solusi sehingga dapat dipilih mana yang terbaikan dalam penyelesaian masalah tata letak perusahaan, meminimumkan aliran material dan mempertimbangkan hubungan kedekatan, kebutuhan ruang dan ruang yang tersedia serta merupakan metode yang sederhana dan lebih mudah untuk diterapkan. Temuan hasil penelitian menunjukkan bahwa tata letak usulan 1 mampu memberikan penghematan biaya material handling sebesar 16,6 \% atau Rp. 1.038,357 tata letak usulan 2 sebesar 22,2\% atau Rp. 1.387,150 dan tata letak usulan 3 sebesar 28,2 \% atau Rp. 1.759,802..
\end{abstract}

Kata kunci: layout, material handling, systematic layout planning

\begin{abstract}
PT. Pan Brothers Tbk Boyolali is a textile company that manufactures various kinds of sportswear. PT. Pan Brothers Tbk Boyolali has several problems related to the layout such as the three largest displacement distances, namely the move from the warehouse table area to the area before inspection of 51.8 meters, the movement from the fabric roll rack area to the c-tex machine area of 35 meters, and transfer from the area before inspection to the quality fabric table area of 34.8 meters. The farther the distance of moving goods the higher the cost of material handling. Another reason for layout improvements needs to be done is the frequent layout changes that are caused by projects from superiors and earlier using any method. Fabric roll material buildup caused by material placement is placed in the alley which obstructs the passage of goods. The total time of production activity in incoming material exceeds the time set by the company, which is 5 to 6 days. Data collection techniques in this study is to conduct direct observation and interviews with workers. With the Systematic Layout Planning (SLP) method, more than one alternative solution can be produced so that it can be chosen which is the best solution in resolving company layout problems, minimizing material flow and considering the close relationship, space requirements and available space and is a simple and more method easy to implement. The findings of the study indicate that the layout of proposal 1 is able to provide material handling cost savings of $16.6 \%$ or Rp. 1,038,357 proposal layout 2 of 22.2\% or Rp. 1,387,150 and proposed layout 3 of 28.2\% or Rp. 1,759,802.
\end{abstract}

Keywords: layout, material handling, systematic layout planning

\section{Pendahuluan}

Peranan Industri Tekstil di Indonesia mempunyai peranan yang cukup signifikan bagi perekonomian khususnya di daerah Jawa Tengah. Badan Pusat Statistik (BPS) tahun 2018 mencatat nilai ekspor secara kumulatif pada Desember 2018 sebanyak US\$162,65 miliar atau meningkat 6,25\% dan terdapat 628 perusahaan serta 147.179 tenaga kerja. Salah satu industri tekstil di Jawa Tengah yang melakukan kegiatan ekspor adalah PT. Pan Brothers Tbk di Boyolali. 
Warehouse pada PT. Pan Brothers Tbk membawahi dua aktivitas, yaitu incoming material dan finishing good. Penelitian ini khusus membahas yang ada di incoming material, dikarenakan pihak perusahaan memberikan batasan proyek evaluasi dilakukan hanya di incoming material saja. Divisi ini bertugas dalam menerima material bahan baku dan menyimpan material dalam jumlah dan rentang waktu tertentu yang kemudian didistribusikan ke stasiun berikutnya.

Berdasarkan hasil observasi, ditemukan beberapa permasalahan yang berkaitan dengan tata letak, yang pertama aliran material produksi belum tertata sehingga menyebabkan jauhnya jarak perpindahan barang. Jarak perpindahan bahan terbesar dari area warehouse table ke area before inspection sebesar 51,8 meter, jarak terbesar kedua yaitu jarak area rak roll kain ke area mesin c-tex sebesar 35 meter, jarak terbesar ketiga yaitu jarak dari area before inspection ke area quality fabric table sebesar 34,8 meter. Dengan jarak perpindahan tersebut, membuat perusahaan memiliki biaya material yang tinggi. Kedua, seringnya terjadi perubahan layout, dalam rentang waktu 3 tahun terakhir. PT. Pan Brothers Tbk sudah melakukan perubahan layout sebanyak 4 kali. Seringnya dilakukan perubahan layout ini disebabkan oleh project dari atasan saja dan belum menggunakan metode apapun. Maka dari itu, perusahaan meminta untuk dilakukan evaluasi dari pihak luar perusahaan agar dapat membuat usulan layout baru dengan tingkat fleksibilitas yang tinggi dan memadai. Ketiga, terjadi penumpukan material roll kain yang disebabkan penempatan material roll kain ditaruh digang yang membuat terhalangkan jalan perpindahan barang. Penumpukan tersebut juga menyusahkan pekerja dalam pengambilan barang. Keempat, proses untuk melakukan aktivitas di incoming material dari material datang sampai siap untuk di distribusikan ke divisi cutting ditetapkan perusahaan yaitu 4 hari. Namun berdasarkan pengamatan, total waktu pada aktivitas di incoming material melebihi waktu yang ditetapkan perusahaan yaitu selama 5 sampai 6 hari. Berdasarkan permasalahan tersebut, PT Pan Brothers Tbk memerlukan perancangan dan perbaikan tata letak fasilitas.

Beberapa penelitian sebelumnya yang menggunakan metode SLP dan berhubungan dan perancangan tata letak fasilitas menghasilkan tata letak usulan yang lebih efektif karena dapat menurunkan besar total momen perpindahan material menjadi $2.515 .500 \mathrm{~m} / \mathrm{tahun}$ dari layout awal sebesar $3.284 .700 \mathrm{~m} /$ tahun. (Anwar dkk., 2015). Penelitian di departemen produksi bagian OT cair pada PT. IKP menghasilkan tata letak usulan yang dapat mengurangi jarak tempuh aliran material sebesar 229,5 meter dan penghematan ongkos material handling sebesar Rp 2.243.570/produk atau sekitar 54,69 \% dari tata letak awal. (Pangestika dkk., 2016). Penelitian lainnya menunjukkan bahwa berdasarkan total biaya penanganan material dan simulasi, tata letak fasilitas usulan kedua dipilih karena mampu mengurangi total biaya penanganan material sebesar 22,92\% dan waktu transfer material sebesar 34,01\%. (Suhardi dkk., 2019). Berdasarkan hal tersebut, maka penelitian ini bertujuan untuk mencari layout terbaik untuk meminimumkan biaya aliran material di PT. Pan Brothers Tbk menggunakan metode SLP. Metode SLP dipilih karena metode ini dapat menghasilkan lebih dari satu alternatif solusi, sehingga dapat dipilih mana yang terbaikan dalam penyelesaian masalah tata letak perusahaan (Naganingrum, 2012).

\section{Metode Penelitian}

Metode Systematic Layout Planning (SLP) digunakan dalam merancang dan memperbaiki tata letak fasilitas di incoming material PT. Pan Brothers Tbk Boyolali. Muther dan Hales (2015) mengatakan metode SLP memiliki 3 keuntungan, yang pertama dapat menghasilkan lebih dari satu alternatif solusi sehingga dapat dipilih mana yang terbaik untuk menyelesaikan permasalahan tata letak perusahaan. Kedua, memiliki langkahlangkah yang terperinci dalam mengatur layout berdasarkan pada urutan prosesnya. Ketiga, mempertimbangkan 5 elemen penting yaitu produk, kuantitas, proses, sistem pendukung, dan waktu.

Pengumpulan data diperoleh dengan melakukan wawancara dan observasi sebagai langkah awal untuk perencanaan tata letak berdasarkan kegiatan penyimpanan dan inspeksi yang berlangsung maupun yang direncanakan (Muthokaroh \& Rois Fatoni, 2017). Data yang yang diperlukan dalam penelitian diantaranya tata letak awal, aliran material, aktivitas produksi, data tenaga kerja, luas area yang tersedia serta jumlah dan ukuran mesin.

Perbaikan tata letak fasilitas alat layout diawali dengan perhitungan jarak perpindahan bahan dengan jarak rectilinier. Pada Penelitian ini menghitung jarak perpindahan dari satu proses ke proses berikutnya menggunakan sistem jarak rectilinear karena perpindahan bahan di perusahaan bergerak secara tegak lurus. Sehingga perhitungan jarak perpindahan bahan dilakukan dengan mengurangi titik koordinat pusat fasilitas pertama dan fasilitas kedua. Titik yang dijadikan acuan yaitu titik input sampai output (Ekoanindiyo \& Wedana, 2012). Sehingga perhitungan jarak rectilinear dapat menggunakan rumus sebagai berikut. 


$$
d_{i j}=\left|x_{i}-x_{j}\right|+\left|y_{i}-y_{j}\right|
$$

Tahap selanjutnya yaitu perhitungan frekuensi perpindahan bahan dan kelompok produk. Pada perhitungan frekuensi perpindahan bahan, dibutuhkan beberapa data seperti total aktivitas per hari dan kapasitas material handling (Hadiguna \& Setiawan, 2008). Langkah pertama adalah menghitung total material handling per hari dengan membagi total aktivitas perhari dengan kapasitas material handling. Setelah itu dilakukan perhitungan frekuensi perpindahan bahan dengan mengkalikan total material handling dengan waktu kerja per bulan. Frekuensi perpindahan bahan ditentukan untuk mengetahui jumlah unit yang dipindahkan dalam sekali perpindahan dan berapa kali perpindahan bahan tersebut dapat dilakukan dalam satuan waktu tertentu. Selanjutnya, akan diklasifikasikan menjadi 3 kelompok produk berdasarkan alat material handlingnya. Hal ini dilakukan karena alat material handling merupakan salah satu faktor penting yang membedakan OMH setiap kelompok produk.

Selanjutnya dilakukan perhitungan ongkos material handling saat ini (OMH). Perhitungan ongkos material handling menggunakan jarak perpindahan dan ongkos perpindahan per meter. Besarnya ongkos ini dipengaruhi oleh aliran material dan tata letak yang digunakan. Dengan mengetahui aktivitas-aktivitas pemindahan yang terjadi maka kita dapat menghitung ongkos material handling. Pada dasarnya setelah ditentukan alat material handling serta jarak untuk setiap pengangkutan, maka OMH dapat diketahui dengan rumus sebagai berikut.

$$
\begin{aligned}
& \text { OMH per meter }=\frac{\text { Gaji per bulan }}{\text { Jarak total }} \\
& \text { Total } O M H=O M H \text { per meter } x \text { jarak pengangkutan } x \text { frekuensi (3) }
\end{aligned}
$$

Tahap berikutnya dilakukan pembuatan From to Chart (FTC). Cara pengisian peta from to chart dilakukan dengan memasukkan nilai total biaya dari tabel ongkos material handling yang disesuaikan dengan pengangkutan bahan dari satu mesin ke mesin lainnya (Nurhasanah \& Simawang, 2013). Kemudian jumlah total biaya setiap baris dan setiap kolom juga total biaya secara keseluruhan. From to Chart menggambarkan tentang total $\mathrm{OMH}$ dari suatu bagian aktivitas dalam pabrik menuju aktivitas dalam pabrik lainnya. Dalam from to chart dapat dilihat total OMH secara keseluruhan.

Selanjutnya dilakukan pembuatan inflow. Pembuatan inflow bertujuan untuk mencari dan mengetahui koefisien ongkos material handling yang masuk ke area aktivitas (Nasution \& Purwanto, 2017). Penggunaan inflow disebabkan karena pemilihan ongkos material dari yang terkecil hingga terbesar sehingga mampu untuk mengurangi biaya yang dikeluarkan. Cara menghitung inflow adalah dengan membagi biaya dari satu departemen ke departemen lain dengan total OMH yang masuk ke departemen tersebut atau dengan rumus sebagai berikut.

$$
\text { Inflow }=\frac{\text { ongkos di mesin } M}{\text { ongkos yang masuk ke mesin } M}
$$

Tahap berikutnya dilakukan pembuatan tabel skala prioritas (TSP). TSP menggambarkan urutan prioritas antar mesin dalam suatu tata letak produksi, sehingga diharapkan ongkos material handling menjadi minimum. Dengan mengetahui harga koefisien biaya pada perhitungan inflow akan didapatkan urutan prioritas. Perhitungan inflow akan dijadikan dasar pertimbangan dalam pembuatan TSP. Dimana prioritas tersebut diurutkan berdasarkan harga koefisien ongkos terbesar sampai dengan yang terkecil.

Berikutnya dilakukan pembuatan Activity Relationship Chart (ARC). ARC adalah bagan aktivitas atau kegiatan antara masing-masing bagian yang menggambarkan tingkat kepentingan kedekatan ruangan (Rosyidi, 2018). Proses operasi bahan baku datang sampai siap untuk dikirim ke stasiun produksi terdiri atas sejumlah aktivitas. Aktivitas akan dianalisis keterkaitannya antara hubungan kegiatan stasiun kerja dengan ARC (Maheswari \& Firdauzy, 2015). Beberapa alasan keterkaitan yaitu mempergunakan peralatan yang sama, urutan aliran kerja, menggunakan ruangan yang sama dan lain sebagainya yang akan disimbolkan dengan huruf A, I, E, O, U, dan X. Huruf-huruf tersebut menunjukkan tingkat kepentingan mulai dari aktivitas yang mutlak penting hingga aktivitas yang tidak diinginkan yang didasari oleh alasan untuk menyatakan tingkat kepentingan tersebut.

Tahap selanjutnya dibuat perancangan tata letak usulan. Dalam perencanaan tata letak usulan, dibutuhkan data luas area kerja saat ini. Luas area kerja diberikan allowance yang terdiri dari ruang gerak operator, perawatan mesin, penumpukan material dan bahan baku, dan gang. Setiap mesin atau fasilitas pendukung 
digunakan toleransi 0,75-1 meter pada setiap sisi mesin dan untuk kelonggaran operator (allowance) sebesar 50\% (Purnomo, 2004). Luas area kerja usulan dapat dihitung dengan rumus sebagai berikut.

Luas mesin $=$ panjang $x($ lebar $+0,75)$

Luas area yang dibutuhkan $=$ Luas mesin $x$ Jumlah mesin

Berikutnya dilakukan perancangan tata letak usulan dan perhitungan ongkos material handling tata letak usulan. Perancangan tata letak usulan dengan membuat tiga alternatif perbaikan dari tata letak fasilitas incoming material. Kemudian dilakukan perhitungan jarak perpindahan bahan pada tata letak fasilitas usulan berdasarkan total jarak perpindahan bahan tersebut. Kemudian dilakukan perhitungan ongkos material handling pada tata letak fasilitas usulan. Tata letak usulan dibuat untuk meminimalkan ongkos material handling, tata letak ini dibuat berdasarkan tata letak saat ini yang sudah ada kemudian disusun kembali berdasarkan ARC, worksheet, ARD, dan tabel skala prioritas yang sudah dibuat (Wignjosoebroto, 2009). Tata letak usulan yang dibuat ada sebanyak 3 alternatif. Perhitungan jarak dan OMH usulan bertujuan untuk mengetahui besarnya jarak antar area kerja dan $\mathrm{OMH} /$ bulan yang dikeluarkan dari tiap usulan yang dibuat.

Tahap terakhir yaitu melakukan perbandingan tata letak saat ini dengan tata letak usulan. Perbandingan tata letak saat ini dengan tata letak usulan bertujuan untuk membandingkan biaya material handling dari kedua tata letak tersebut sehingga dapat diketahui dan dipilih tata letak yang memiliki ongkos material handling yang paling rendah (Triyono dkk., 2014).

\section{Hasil dan Pembahasan}

\section{Layout Awal}

Layout Awal adalah kondisi aktual yang ada di incoming material saat ini, dengan data layout awal ini menjadi dasar dalam merancang layout alternatif. Berikut adalah gambar layout awal incoming material:

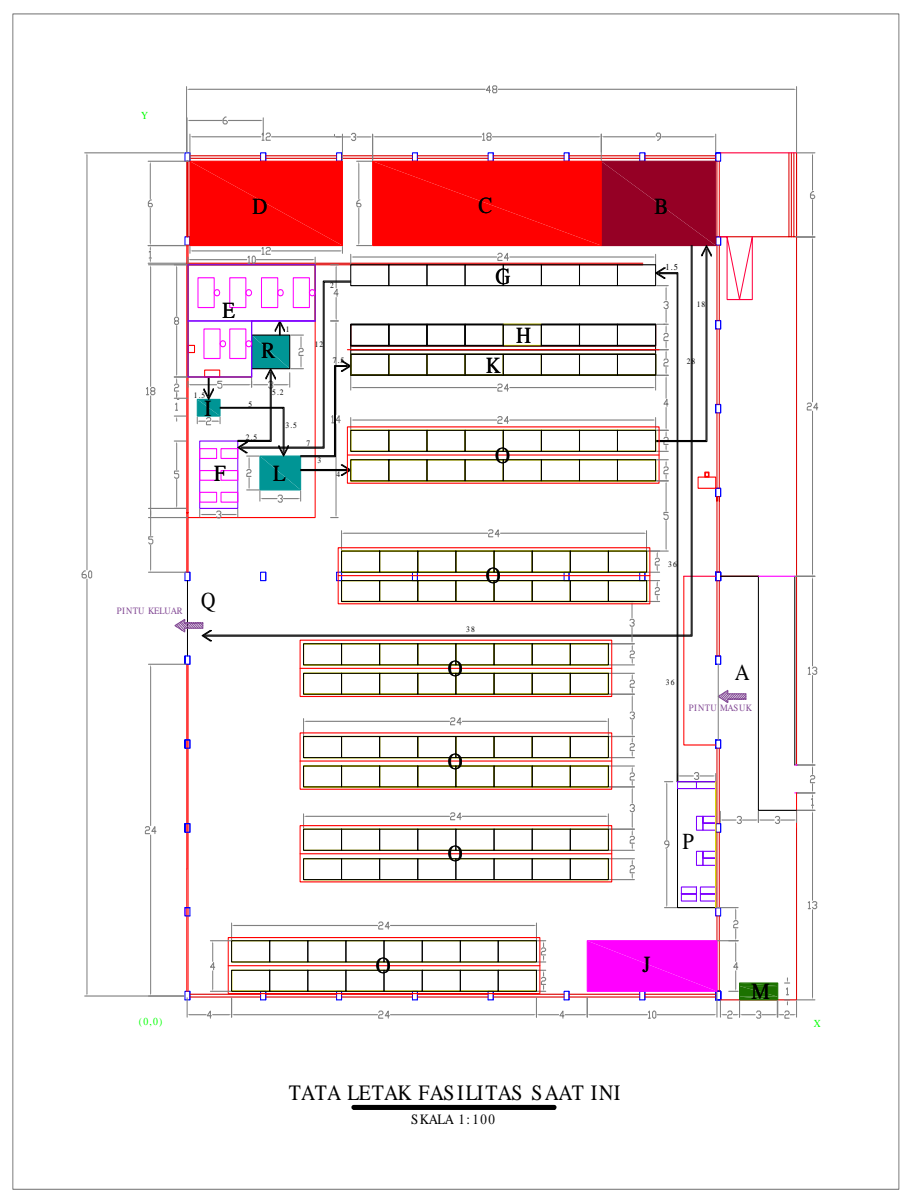

Gambar 1. Layout Awal Incoming Material 
Penelitian ini menggunakan metode rectilinear untuk menghitung jarak perpindahan bahan dari satu proses ke proses selanjutnya. Sistem perpindahan bahan pada bidang tata letak fasilitas warehouse sangat sesuai apabila menggunakan perhitungan jarak rectilinear karena perpindahan bahan bergerak tegak lurus. Berikut adalah jarak perpindahan bahan antar area kerja yang ditunjukkan pada Tabel 1.

Tabel 1. Jarak Perpindahan Bahan Antar Area Kerja

\begin{tabular}{|c|c|c|c|c|}
\hline \multicolumn{2}{|c|}{ Urutan Proses } & \multirow{2}{*}{$\begin{array}{c}\text { Alat } \\
\text { Angkut }\end{array}$} & \multirow{2}{*}{ Komponen } & \multirow{2}{*}{ Jarak (m) } \\
\hline Dari & Ke & & & \\
\hline \multirow{2}{*}{$\mathrm{P}$} & \multirow{2}{*}{$\mathrm{G}$} & Forklift & Roll kain & 51,8 \\
\hline & & Handlift & Box aksesoris & 51,8 \\
\hline \multirow{2}{*}{ G } & \multirow{2}{*}{$\mathrm{F}$} & Manusia & Potongan kain & 34,8 \\
\hline & & Manusia & Sample aksesoris & 34,8 \\
\hline $\mathrm{F}$ & $\mathrm{R}$ & Manusia & Roll kain & 13,5 \\
\hline $\mathrm{R}$ & $\mathrm{E}$ & Manusia & Roll kain & 11 \\
\hline E & I & Manusia & Sample kain & 15,5 \\
\hline $\mathrm{I}$ & $\mathrm{L}$ & Manusia & Sample aksesoris & 27,8 \\
\hline $\mathrm{L}$ & $\mathrm{K}$ & Manusia & Sample material & 19,5 \\
\hline \multirow{2}{*}{$\mathrm{L}$} & \multirow{2}{*}{$\mathrm{O}$} & Handlift & Roll kain & 19,5 \\
\hline & & Handlift & Box aksesoris & 19,5 \\
\hline $\mathrm{O}$ & $\mathrm{B}$ & Handlift & Roll kain & 35 \\
\hline \multicolumn{4}{|c|}{ Total } & 259 \\
\hline
\end{tabular}

Selanjutnya dilakukan perhitungan frekuensi dari material handling antar area kerja yang ditunjukkan pada tabel 2 berikut ini.

Tabel 2. Frekuensi Material Handling Antar Area Kerja

\begin{tabular}{|c|c|c|c|c|c|c|c|}
\hline Dari & $\mathbf{K e}$ & Alat Angkut & Komponen & $\begin{array}{c}\text { Total } \\
\text { Aktivita } \\
\text { s per } \\
\text { Hari } \\
\text { (Unit) } \\
\text { (d) }\end{array}$ & $\begin{array}{c}\text { Kapasitas } \\
\text { Material } \\
\text { Handling } \\
\text { (Unit) (e) }\end{array}$ & $\begin{array}{c}\text { Total } \\
\text { Material } \\
\text { Handling } \\
\text { per Hari } \\
\begin{array}{c}\text { (f) }=(\text { d) } / \\
(\text { e) }\end{array}\end{array}$ & $\begin{array}{c}\text { Frekuensi } \\
(\mathrm{g})=(\mathbf{f}) \mathrm{x} \\
24 \text { hari }\end{array}$ \\
\hline \multirow{2}{*}{$\mathrm{P}$} & \multirow{2}{*}{ G } & Forklift & Roll kain & 48 & 22 & 3 & 72 \\
\hline & & Handlift & Box Aksesoris & 10 & 5 & 2 & 48 \\
\hline \multirow{2}{*}{ G } & \multirow{2}{*}{$\mathrm{F}$} & \multirow{2}{*}{ Manusia } & $\begin{array}{c}\text { Sample Kain } \\
(29,6 \mathrm{~cm} \times 21 \mathrm{~cm}) \\
\end{array}$ & 48 & 24 & 2 & 48 \\
\hline & & & $\begin{array}{l}\text { Sample Aksesoris } \\
(29,6 \mathrm{~cm} \times 21 \mathrm{~cm}) \\
\end{array}$ & 10 & 10 & 1 & 24 \\
\hline $\mathrm{F}$ & $\mathrm{R}$ & Manusia & Roll kain & 48 & 1 & 48 & 1152 \\
\hline $\mathrm{R}$ & $\mathrm{E}$ & Manusia & Roll kain & 48 & 1 & 48 & 1152 \\
\hline $\mathrm{E}$ & I & Manusia & $\begin{array}{c}\text { Sample Kain } \\
(29,6 \mathrm{~cm} \times 21 \mathrm{~cm})\end{array}$ & 48 & 24 & 2 & 48 \\
\hline I & $\mathrm{L}$ & Manusia & $\begin{array}{l}\text { Sample Aksesoris } \\
(29,6 \mathrm{~cm} \text { x } 21 \mathrm{~cm})\end{array}$ & 10 & 10 & 1 & 24 \\
\hline $\mathrm{L}$ & $\mathrm{K}$ & Manusia & Sample Material & - & - & - & - \\
\hline \multirow{2}{*}{$\mathrm{L}$} & \multirow{2}{*}{$\mathrm{O}$} & \multirow{2}{*}{ Handlift } & Roll Kain & 480 & 10 & 48 & 1152 \\
\hline & & & Box Aksesoris & 100 & 10 & 10 & 240 \\
\hline $\mathrm{O}$ & $\mathrm{B}$ & Handlift & Roll Kain & 80 & 10 & 8 & 192 \\
\hline
\end{tabular}

Setelah dilakukan perhitungan frekuensi dari material handling antar area kerja, selanjutnya dilakukan perhitungan total ongkos material handling per bulan yang ditunjukkan pada tabel 3 berikut ini. 
Tabel 3. Perhitungan OMH Saat Ini

\begin{tabular}{|c|c|c|c|c|c|c|c|c|}
\hline \multirow{3}{*}{$\underset{\text { Dar }}{\text { i }}$} & \multirow{3}{*}{$\mathbf{K e}$} & \multirow{3}{*}{ Komponen } & \multirow{3}{*}{$\begin{array}{c}\text { Alat } \\
\text { Angkut }\end{array}$} & \multirow{3}{*}{$\begin{array}{l}\text { Frekuensi } \\
\text { (g) }\end{array}$} & \multirow{3}{*}{$\begin{array}{l}\text { Jarak } \\
\text { (m) (h) }\end{array}$} & & \multirow{3}{*}{$\begin{array}{c}\text { OMH/meter } \\
\text { (Rp) (j) }\end{array}$} & \multirow{3}{*}{$\begin{array}{c}\text { Total OMH / } \\
\text { bulan (Rp) } \\
(\mathbf{k})=(\mathbf{i}) \times(\mathbf{j})\end{array}$} \\
\hline & & & & & & $\begin{array}{c}\text { Total } \\
\text { Jarak } \\
(\mathbf{m})\end{array}$ & & \\
\hline & & & & & & $\begin{array}{l}(\mathbf{i})=(\mathbf{g}) \\
\mathbf{x}(\mathbf{h})\end{array}$ & & \\
\hline \multirow{2}{*}{$\mathrm{P}$} & \multirow{2}{*}{$\mathrm{G}$} & Roll kain & Forklift & 72 & 51.8 & 3729.6 & 432 & IDR1,611,187 \\
\hline & & Box Aksesoris & Handlift & 48 & 51.8 & 2486.4 & 50 & IDR124,320 \\
\hline \multirow[b]{2}{*}{ G } & \multirow[b]{2}{*}{$\mathrm{F}$} & Potongan Kain & \multirow[b]{2}{*}{ Manusia } & 48 & 34.8 & 1670.4 & 87 & IDR145,325 \\
\hline & & $\begin{array}{l}\text { Sample } \\
\text { Aksesoris }\end{array}$ & & 24 & 34.8 & 835.2 & 87 & IDR72,662 \\
\hline $\mathrm{F}$ & $\mathrm{R}$ & Roll kain & Manusia & 1152 & 13.5 & 15552 & 87 & IDR $1,353,024$ \\
\hline $\mathrm{R}$ & $\mathrm{E}$ & Roll kain & Manusia & 1152 & 11.5 & 13248 & 87 & IDR1,152,576 \\
\hline $\mathrm{E}$ & $\mathrm{I}$ & Sample Kain & Manusia & 48 & 15.5 & 744 & 87 & IDR64,728 \\
\hline I & $\mathrm{L}$ & $\begin{array}{l}\text { Sample } \\
\text { Aksesoris }\end{array}$ & Manusia & 24 & 15 & 360 & 87 & IDR31,320 \\
\hline $\mathrm{L}$ & $\mathrm{K}$ & Sample Material & Manusia & 0 & 15 & 0 & 87 & - \\
\hline \multirow{2}{*}{$\mathrm{L}$} & \multirow{2}{*}{$\mathrm{O}$} & Roll Kain & Handlift & 1152 & 19.5 & 22464 & 50 & IDR $1,123,200$ \\
\hline & & Box Aksesoris & Handlift & 240 & 19.5 & 4680 & 50 & IDR234,000 \\
\hline $\mathrm{O}$ & $\mathrm{B}$ & Roll Kain & Handlift & 192 & 35 & 6720 & 50 & IDR336,000 \\
\hline \multicolumn{4}{|c|}{ Total } & 4152 & 317.7 & 72489.6 & 1241 & IDR6,248,342 \\
\hline
\end{tabular}

Setelah didapatkan total ongkos material handling, selanjutnya membuat tabel from to chart dan tabel inflow dengan mengurutkan berdasarkan kegiatan satu ke kegiatan lain dengan melihat ongkos material handling yang ditunjukkan pada tabel 4 dan 5 dibawah ini.

Tabel 4. From To Chart

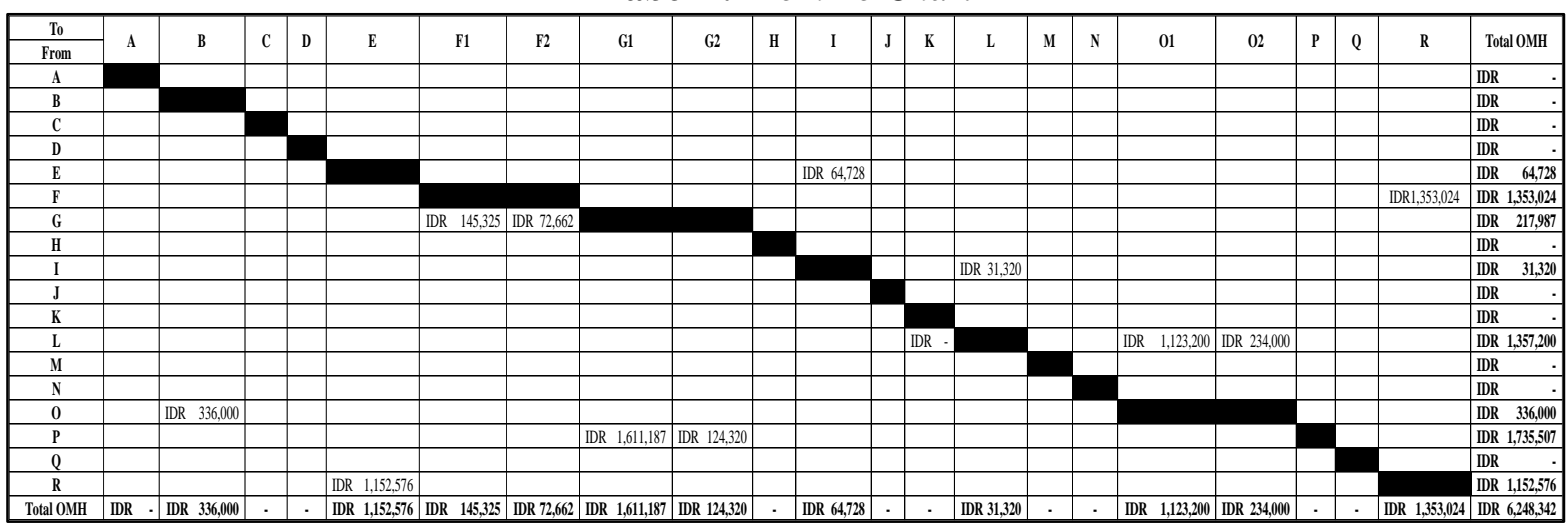

Tabel 5. Inflow

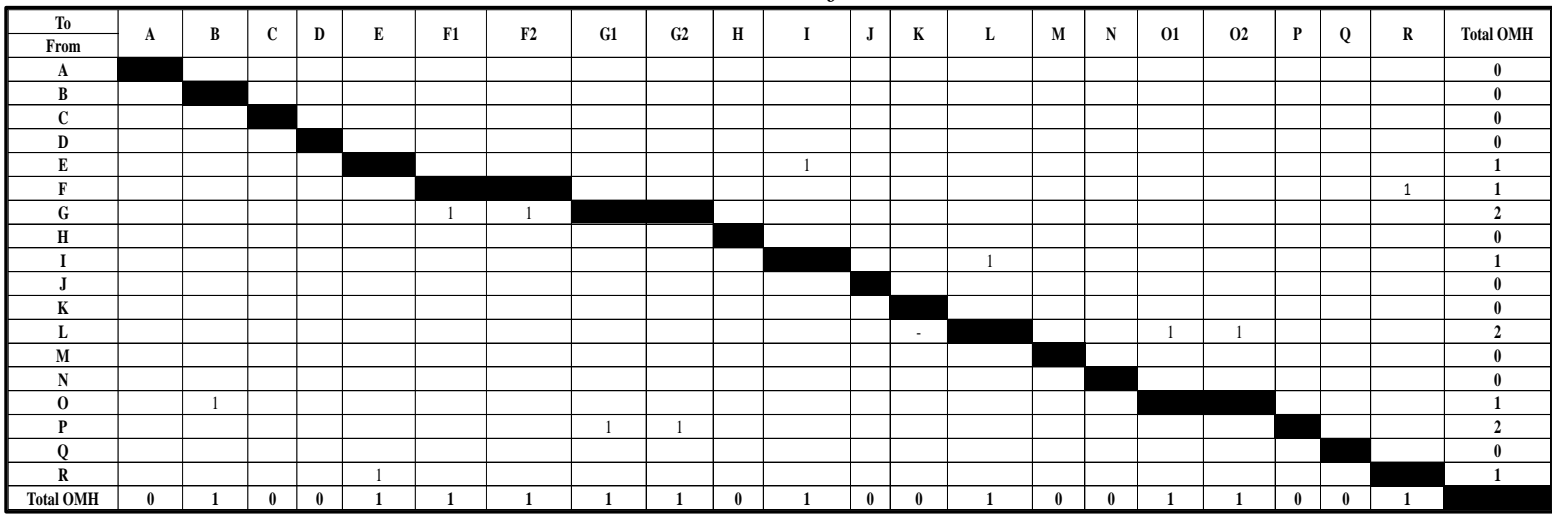


Setelah dibuat tabel FTC dan inflow, selanjutnya dibuat tabel skala prioritas berdasarkan harga koefisien ongkos terbesar sampai dengan yang terkecil. Kemudian dibuat activity relationship chart untuk menggambarkan tingkat kepentingan kedekatan ruangan Berikut adalah tabel skala prioritas yang ditunjukkan pada tabel 6 dan ARC pada gambar 2 berikut ini.

Tabel 6. Tabel Skala Priorotas

\begin{tabular}{|c|l|c|c|c|}
\hline \multirow{2}{*}{ No } & \multirow{2}{*}{ Area Kerja } & \multirow{2}{*}{ Kode } & \multicolumn{2}{|c|}{ Prioritas } \\
\cline { 5 - 6 } & & I & & II \\
\hline 1 & Pintu Belakang & B & O & \\
\hline 2 & Area Relaksasi Kain & C & & \\
\hline 3 & Area penyimpanan mesin jahit 1 & D & & \\
\hline 4 & Area penyimpanan mesin jahit 2 & E & I & \\
\hline 5 & Area Inspeksi Kain & F & R & \\
\hline 6 & Area Inspeksi Pembelian Material & G & F & \\
\hline 7 & Area penyimpanan material sebelum inspeksi & H & & \\
\hline 8 & Area penyimpanan material bahan baku & I & L & \\
\hline 9 & Area pengecekan warna di light box & J & & \\
\hline 10 & Area penyimpanan material dark room & K & H & \\
\hline 11 & Area penyimpanan material reject & L & O & K \\
\hline 12 & Area pengecekan kontaminasi logam & P & G & \\
\hline 13 & Area penerimaan material & Q & & \\
\hline 14 & Area pemindahan material ke stasiun produksi & R & E & \\
\hline 15 & Area Pengecekan warna di mesin $c$-tex & & & \\
\hline
\end{tabular}

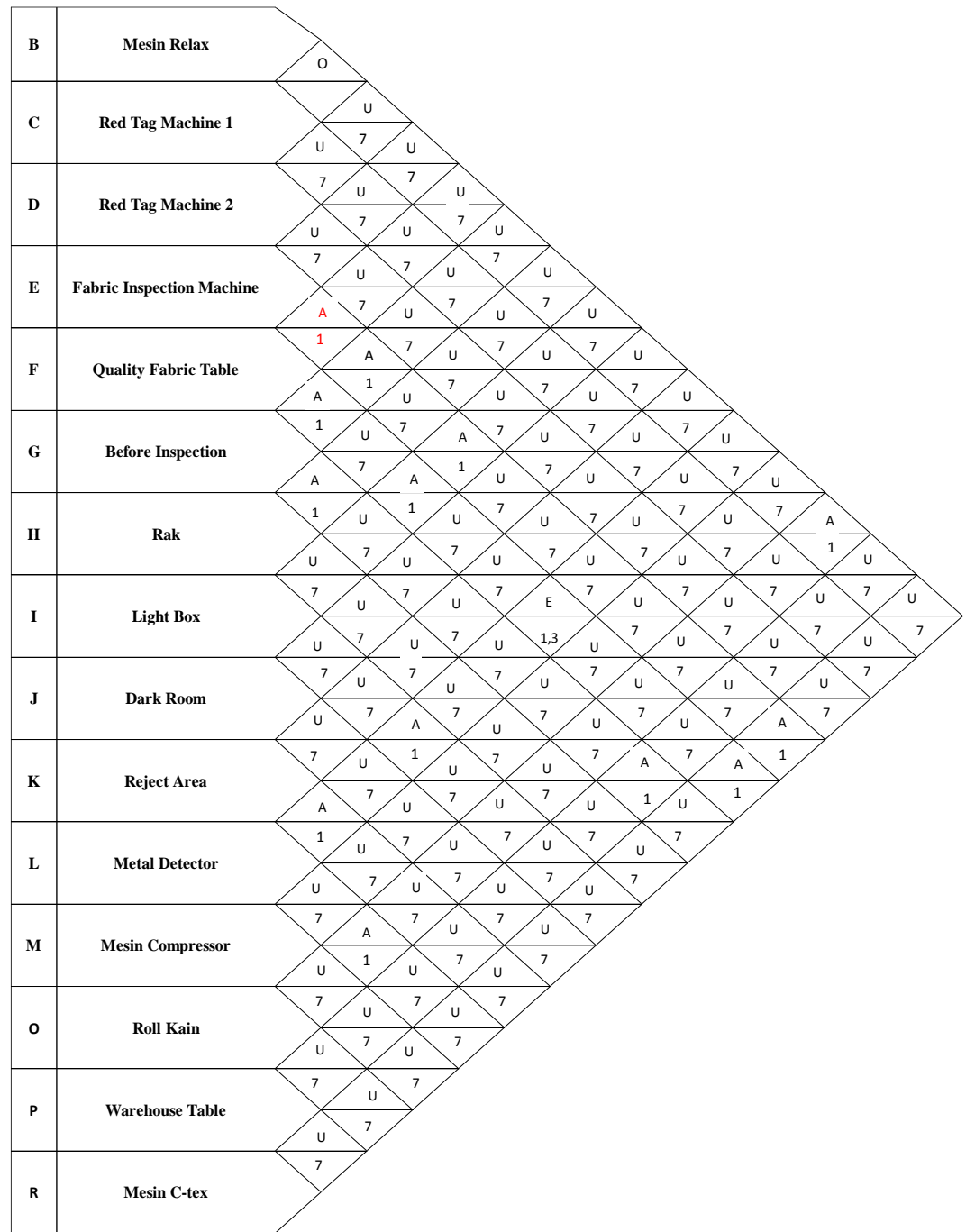

Gambar 2. Activity Relationship Chart 
Analisis Perhitungan Ongkos Material Handling dan Luas Area Kerja

Berdasarkan perhitungan yang telah dilakukan pada layout awal dan usulan, maka akan disajikan tabel perbandingan antara layout awal dan alternatif sebagai alternative yang lebih ditekomendasilkan untuk digunakan karena mendapatkan luas area kerja dan ongkos material handling yang kecil.

Tabel 7. Perbandingan Total OMH

\begin{tabular}{|l|c|c|c|c|}
\hline \multicolumn{1}{|c|}{ Perbedaan } & $\begin{array}{c}\text { Luas Area } \\
\text { Kerja } \\
\left(\mathbf{m}^{\mathbf{2}}\right)\end{array}$ & $\begin{array}{c}\text { Persentase } \\
\text { Penurunan } \\
\text { Jarak }\end{array}$ & $\begin{array}{c}\text { Total } \\
\text { OMH/bulan }\end{array}$ & $\begin{array}{c}\text { Persentase } \\
\text { Penurunan } \\
\text { Total OMH }\end{array}$ \\
\hline Kondisi Awal & 936,76 & - & $\mathrm{Rp} \mathrm{6.248,342}$ & - \\
\hline Tata Letak Usulan 1 & 890,76 & $4,95 \%$ & $\mathrm{Rp} \mathrm{5.209,985}$ & $16,6 \%$ \\
\hline Tata Letak Usulan 2 & 890.76 & $4,95 \%$ & $\mathrm{Rp} 4.863,192$ & $22,2 \%$ \\
\hline Tata Letak Usulan 3 & 885,15 & $5,46 \%$ & $\mathrm{Rp} \mathrm{4.488,540}$ & $28,2 \%$ \\
\hline
\end{tabular}

\section{Simpulan}

Berdasarkan pengamatan secara langsung terkait dengan kondisi tata letak fasilitas pada incoming material saat ini menunjukkan bahwa adanya perpindahan material yang belum optimal dan perlu dilakukan suatu perbaikan. Perancangan tata letak fasilitas menghasilkan tiga alternatif tata letak fasilitas usulan. Dari ketiga alternatif yang diusulkan, dipilih satu alternatif yang paling optimal yaitu tata letak fasilitas usulan 3. Pemilihan usulan 3 dikarenakan tata letak fasilitas usulan ini memiliki total jarak perpindahan bahan yang terkecil yaitu sebesar 242 meter. Tata letak fasilitas usulan ini lebih pendek dari tata letak fasilitas saat ini dengan perbedaan total jarak perpindahan bahan sebesar 75,7 meter atau 23,8\%. Sedangkan total OMH untuk tata letak fasilitas usulan 3 memiliki biaya yang paling rendah yaitu sebesar Rp 4.488,540 per bulan. Pada tata letak fasilitas usulan ini terjadi penghematan total OMH sebesar Rp. 1.759,802 per bulan atau 28,2\%. Berdasarkan hal tersebut, diharapkan dengan diterapkannya layout usulan 3, perusahaan dapat melakukan penghematan ongkos material handling sebesar 28,2\% atau menghemat sebesar Rp 1.759.802,- per bulannya.

\section{Daftar Pustaka}

Anwar, A., Bakhtiar, B., \& Nanda, R. (2017). Usulan Perbaikan Tata Letak Pabrik dengan Menggunakan Systematic Layout Planning (SLP) di CV. Arasco Bireuen. Industrial Engineering Journal, 4(2).

Ekoanindiyo, F. A., \& Wedana, Y. A. (2012). Perencanaan Tata Letak Gudang Penggunakan Metode Shared Storage Di Pabrik Plastik Kota Semarang. Jurnal Ilmiah Dinamika Teknik, 6(1).

Hadiguna, A. R., \& Setiawan, H. (2008). Tata Letak Pabrik. Andi Offset. Yogyakarta.

Maheswari, H., \& Firdauzy, A. D. (2015). Evaluasi Tata Letak Fasilitas Produksi Untuk Meningkatkan Efisiensi Kerja Pada PT. Nusa Multilaksana. Jurnal Ilmiah Manajemen dan Bisnis Mercu Buana, 1(3), 97078.

Muther, R., \& Hales, L. (2015). Systematic Layout Planning $4^{\text {th }}$ Edition. USA: Management and Industrial Research Publication

Muthoharoh, A., \& Rois Fatoni, S. T. (2017). Analisis K3 dan Perancangan Ulang Tata Letak di Industri Pengecoran Logam Dengan Menggunakan Metode SLP (Systematic Layout Planning). (Doctoral dissertation, Universitas Muhammadiyah Surakarta).

Naganingrum, R. P. (2012). Perancangan Ulang Tata Letak Fasilitas di PT. Dwi Komala dengan Metode Systematic Layout Planning. Skripsi. Surakarta: Universitas Sebelas Maret.

Nasution, S. R., \& Purwanto, H. (2017). Rancangan Ulang Tata Letak Mesin di PT. Korosi Specindo. Jurnal Ilmiah Teknik Industri, 3(1).

Nurhasanah, N., \& Simawang, B. P. (2013). Perbaikan Rancangan Tata Letak Lantai Produksi di CV. XYZ. Jurnal AlAzhar Indonesia Seri Sains dan Teknologi, 2(2), 81-90

Pangestika, J. W., Handayani, N., \& Kholil, M. (2017). Usulan Re-Layout Tata Letak Fasilitas Produksi Dengan Menggunakan Metode SLP Di Departemen Produksi Bagian OT Cair Pada PT. IKP. JISI: Jurnal Integrasi Sistem Industri, 3(1), 29-38.

Purnomo, H. (2004). Perencanaan dan Perancangan Fasilitas, Edisi Pertama. Yogyakarta: Graha Ilmu

Rosyidi, M. R. (2018). Analisa Tata Letak Fasilitas Produksi dengan Metode ARC, ARD, dan AAD di PT. XYZ. WAKTU, $16(1), 82-95$.

Suhardi, B., Juwita, E., \& Astuti, R. D. (2019). Facility Layout Improvement In Sewing Department With Systematic Layout Planning And Ergonomics Approach. Cogent Engineering, 6(1), 1597412.

Triyono, T., Cundara, N., \& Irwan, H. (2014). Usulan Perbaikan Tata Letak Fasilitas Perkantoran di PT. BPR Mitra Arta Mulia Bengkalis Riau. PROFISIENSI, 2(2).

Wignjosoebroto, S. (2009). Tata Letak Pabrik dan Pemindahan Bahan. Edisi Ketiga. Surabaya: Penerbit Guna Widya. 